\title{
Nothing More to See - Contestations of Belonging and Visibility in Russian Media
}

\author{
Emil Edenborg \\ Lund \& Malmö: Lund Political Studies 177 / Malmö Studies in Global Politics 12016 \\ 244 sidor. ISBN Lund University 9789176237052, ISBN Malmö University \\ 9789171046680
}

Recenserad av: Jussi Lassila [ph.d., docent, Aleksanteri Institute, University of Helsinki, jussi.lassila@helsinki.fi]

Emil Edenborgs doktorsavhandling Nothing more to see - Contestations of belonging and visibility är ett viktigt och välkommet bidrag, inte bara för forskningen kring Ryssland, utan även metodologiskt för en kvalitativ samhällsanalys där medierna och den politiska relevansen står i fokus. I synnerhet i det sjunde kapitlet koncentrerar sig avhandlingen på synligheten av de akuta temaområdena i dagens Ryssland och den definitionskamp som detta medför då det handlar om beskrivningar om att ingå i samhället, eller med andra ord tillhörighetens politik (politics of belonging). Utgångspunkten är uppfattningen om moderna medier som ett utrymme där »världen framträder» (s. 16). Medierna är alltså inte transparenta förmedlare av representationer och deras roll kan inte reduceras till ett enskilt mediums politiska eller samhälleliga status. Däremot uppfattas medier som hybrider, det vill säga som ramar där såväl traditionell som modern mediepraxis blandas upp. Dessa ramar definierar vad som kan ses och höras. På grundval av dessa inskränkande ramar skapas även de möjligheter som bidrar till att spränga gränserna för vad som kan höras och ses.

Edenborgs val kan anses vara lyckat, eftersom detta perspektiv på ett naturligt sätt länkar samman medierna till en oskiljaktig del av vårt moderna samhälle och våra politiska duster. I och för sig har detta redan länge varit ett välkänt faktum. Ur akademisk infallsvinkel har man inte kunnat ta till sig detta på ett lika naturligt sätt. Man har framhävt antingen medierna eller politiken, eller så har försöken att sammanlänka dessa två drunknat i en uppsjö av konkurrerande teorier. Även i Edenborgs avhandling finns det på vissa håll alltför många teoretiska infallsvinklar som går i olika riktningar och tidvis belastar läsaren. Som helhet sett kan doktorsavhandlingen emellertid anses vara imponerande kompakt.

Andra kapitlet i denna bok diskuterar tillhörighetens politik i förhållande till synlighet (arrangements of visibility) och hade med tanke på avhandlingen som helhet fungerat bättre $\mathrm{i}$ en nedbantad form och med direkta kopplingar till Ryssland 
som kontext. Exempelvis inledningen av detta kapitel från sidan 49 och framåt hade på detta sätt blivit mer slagkraftig och mindre belastande för läsaren. Åtskillnaden mellan internalisering av synligheten, stärkande av synligheten och ifrågasättande av synligheten (containing, amplifying och contesting visibility, s. 57) hade kunnat skrivas in i någon form av schema för att göra det enklare för läsaren att följa med resonemanget och få en tydligare uppfattning om det. I övrigt är åtskillnaden mellan de olika delområdena lyckad och fungerar väl i fallstudierna.

Avhandlingen innehåller följande frågeställning: »How can we understand the role of visibility in the production and the contestation of belonging to a political community?» (s. 13). Edenborg närmar sig denna frågeställning via tre fallstudier: fallet med förbudet mot homosexualitetspropaganda, fallet med de olympiska spelen i Sotji och fallet med kriget i Ukraina. Alla dessa tre fall kan på ett trovärdigt sätt kopplas till samhällsklimatet och utvecklingen i Ryssland under de senaste åren. Frågan om vad dessa fall representerar i förhållande till frågan om tillhörighet eller icke-tillhörighet till en gemenskap är särskilt aktuell. Forskningsmaterialet utgörs av det material som samlats ur ryska medier (tidningar, TV, internet) ända från början av år 2013 och fram till början av år 2015, vid sidan om forskningsresor ute på fältet, intervjuer med representanter för frivilligorganisationer samt kritiska journalister.

Särskilt lyckad är Edenborgs analys om de representationer och icke-representationer som bygger på förbudet mot homosexualitetspropaganda (kapitel 4). I detta kapitel visar avhandlingsförfattaren prov på mogen och skicklig kontextualisering, där den moralpanik som förekommer i Ryssland, i synnerhet med anknytning till sexualitet, inte direkt kopplas till enkelspåriga uppfattningar om landets efterblivenhet, utan ses som en fascinerande frågeställning $\mathrm{i}$ förhållande till traditionerna och det moderna samhället. Rysslands osäkerhet då det gäller landets egen identitet framträder i form av förakt mot »det homosexuella Europa», samtidigt som man anpassar sig till detta men står i försvarsposition. Å andra sidan uttrycker sig denna osäkerhet som en säkerhetsfråga eller rentav existentiell fråga för »det sanna och moraliska Europa», det vill säga Ryssland, som värnar om traditionella värderingar. Analysen flyter fram fint med hjälp av belysande exempel ur forskningsmaterialet, där man granskar hållbarheten av »den hegemoniska grammatiken» om homosexualitet, liksom även bristerna i denna grammatik, nämligen de metoder som ifrågasätter de rådande representationerna. Edenborg speglar sin analys på ett träffsäkert sätt både mot exempel från västvärlden och mot Rysslands egen identitetspolitiska historia. I ljuset av denna utmärkta fallstudie vore det intressant att veta hur diskursen om homosexualitet har levt vidare $\mathrm{i}$ de ryska medierna exempelvis under de senaste femton åren i form av en kamp om tillhörighet till det traditionella eller det moderna samhället. Uppstod hela denna diskurs i denna omfattning först i samband med lagens ikraftträdande år 2013? Vad fanns det i så fall före detta, och är diskursen år 2016 likadan som i Edenborgs analys?

Den andra fallstudien granskar de olympiska spelen i Sotji. Edenborg framhäver rollen av vinterspelen i Sotji som olympiska spel och lokaliserar dessa med fog som ett särskilt tillhörighetens spektakel (spectacle of belonging), vilket framhävs i öppnings- och avslutningsceremonierna för dessa vinterspel. Eftersom Sotji var en form av spektakel för nationell tillhörighet aktiverades inom dessa ramar även det 
officiella Rysslands behov av att projicera sig själv inte bara som en stormakt som bemästrar politiska tvister och politisk kritik, utan även som ett regionalpolitiskt moderniseringsprojekt (det vill säga vid moderniseringen av de södra delarna av Ryssland). Analysen är belysande på alla sätt, men den astronomiska korruptionen som förekom i samband med organisationen av de olympiska spelen kunde ha uppmärksammats mer. På vilket sätt representerade de officiella representationerna denna sida, hur lät de bli att representera denna sida, eller hur kompenserade de detta? Korruptionens roll hade kunnat tilläggas till de former av representation som ifrågasatte den officiella sidan av de olympiska spelen. För dessa representationer har Edenborg valt för det första de sexuella minoriteternas ställning i Ryssland och under de olympiska spelen, vilket fick bred uppmärksamhet, för det andra terrorismen, vilket har att göra med Kaukasiens geografiska närhet, samt för det tredje de synnerligen intressanta exemplen på cherkessisk nationalism, som historiskt sett har haft ett visst inflytande på området kring Sotji.

Den tredje fallstudien handlar om kriget $\mathrm{i}$ Ukraina och framför allt sådana metoder för visualisering som ifrågasätter de officiella representationerna. Först undersöker Edenborg satiren och dess särskilda underordnade form stjob, och fastställer vilken roll denna form av satir spelar i kritiken av de officiella synsätten och vid anpassningen till de officiella synsätten. Det finns belysande exempel på hur den ryska stormaktens skrävel parodieras, men stjobs roll kunde ha dryftats närmare $\mathrm{i}$ förhållande till dess roll som politisk aktör eller i förhållande till politiska identiteter. När fungerar stjobs möjligheter att sudda ut gränserna mellan kritik och anpassning till det officiella synsättet, och när fungerar dessa möjligheter å andra sidan inte? Har stjobs ambivalens anknytning till just det faktum att de politiska rörelserna i Ryssland institutionellt sett är alltför svaga för att framföra sina egna synpunkter?

I den senare delen av detta kapitel granskas kriget i Ukraina särskilt till de delar som är mest problematiska i det ryska officiella synsättet, nämligen att det finns ryska soldater som kämpar där, och framför allt hur man i offentligheten hanterar de soldater som stupat i kriget där. Här kommer Edenborgs arbete till sin rätt, då han koncentrerar sig på synlighet och tillhörighetens politik. Avhandlingsförfattaren kombinerar på ett fint sätt olika teman från de tidigare kapitlen, i synnerhet teman gällande könsordningen. Bland annat $\mathrm{i}$ fråga om dem som stupat $\mathrm{i}$ kriget och som döljs från offentligheten visar Edenborg hur de rådande könsnormerna i Ryssland gällande maskulint hjältemod samt sörjande mödrar och hustrur vänds emot de officiella förklaringarna.

Den sista delen av avhandlingen innehåller spännande resonemang kring vidare forskning. Detta inspirerar till att ställa frågan om hur de samhälleliga och politiska fenomenen i Ryssland förhåller sig till andra postauktoritära eller nyauktoritära samhällen. I synnerhet med avseende på sexuella minoriteter vore det intressant att veta hur synligheten eller osynligheten samt utestängningen av vissa grupper kan jämföras med situationen $i$ andra konservativa samhällen. Hur inskränks eller döljs »omoraliska» sammanslutningar till exempel i Ukraina, under den politiska polariseringen mot Ryssland? $\AA$ andra sidan vore det intressant att veta hur politiska identiteter och positioner sammanlänkas med de utvalda representationerna och de 
politiska konjunkturerna. Efter Sovjetunionens fall har man i Ryssland kunnat iaktta avsevärda svängningar i fråga om politiska positioner och värdeorientering. Hur sammanlänkas sega associationer (sticky associations) med dessa positioner i fråga om vissa utvalda representationer? Hur sega är de när det kommer till kritan?

Som metodologisk och teoretisk kontribution skiljer sig Edenborgs analys därvid inte från sådana diskursanalyser där man bedömer »dolda kontexter», om man ser på avhandlingsförfattarens analys av skälen och motiven till varför vissa aspekter inte framförs/uttalas, eller varför de representeras i en viss ordning. Edenborgs sofistikerade teoretiska resonemang om visualiteten och tillhörighetens politik skapar emellertid rikligt med utrymme och en bred horisont för fortsatta studier. Detta är något som få doktorsavhandlingar uppnår. Det är särskilt beundransvärt att avhandlingsförfattaren har en förmåga att tillämpa sin västerländska poststrukturella teoribakgrund på ett kritiskt sätt i fallet Ryssland, där författaren hela tiden beaktar det ryska samhället och den ryska historieskrivningen. 